\section{Destruction of Scientific Institutes in the Philippines}

INFORMATION has been received that the buildings of the Bureau of Science, Manila, have been utterly destroyed in the fighting for that city; and, moreover, it is reported that the Japanese have destroyed the Philippine College of Agriculture at Los Banos, eastward of Manila. The loss of the scientific collections and libraries in the Bureau of Science is irreparable. The Bureau took shape in January 1906 by the union of the Bureaux of Government Laboratories and Mines, and was charged with investigations in bacteriology, immunity, prophylaxis, etiology, botany, various branches of zoology (in particular entomology), technological chemistry, geology and mining engineering. The whole structure has gone-the records of the work of forty years; for the two Bureaux named had been at work for four years before the Bureau of Science was formed.

Botany has been singularly hard hit and singularly ill-fated in the Philippines. The collections which Sebastian Vidal made when he was inspector of forests towards the end of the Spanish regime were lost in an accidental fire in 1897, and those of the Augustinian Friars burned when the Guadalupe Monastery was destroyed in the fighting in 1899; in consequence of this, Dr. E. D. Merrill, who went to Manila in 1902 as Government botanist, had to begin his work without foundations on the spot. $\mathrm{He}$ gathered together a herbarium unique in its facilities for study of Philippine botany and a botanical library second to none in Asia. These have gone. His four-volumed "Enumeration of Philippine Flowering Plants" (1922-26) preserves a part of the records; but beyond collections from the islands, the herbarium held a great amount of comparable material from all parts of the East.

\section{Spectroscopically Standardized Substances}

As the use of the spectrograph for the detection and determination of the metallic elements in all kinds of materials increased, there arose a demand for extremely pure metals, oxides and salts to serve as standards. About 1922 Dr. S. Judd Lewis suggested to Messrs. Adam Hilger, Ltd., that they should supply for this purpose spectroscopically standardized sub. stances; the proposal was adopted, all arrangements for the supply of the substances and their analysis being in the hands of Dr. Judd Lewis. These pure substances have become well known under the trade mark of "H. S." Substances, and now include most of the more common and many of the rarer metals, as well as most of the rare earth oxides. In 1932, when Dr. Judd Lewis proposed the 'ratio quantitative' method of spectrographic analysis, the 'Specpure' series of 'ratio powders', 'ratio solutions' and pure salts was introduced, and now comprises more than fifty substances which are available in a spectrographically standardized condition. Every supply of "H. S." or "Specpure" material has always been accompanied by a full report of the results of chemical and spectrographic examinations made on that material. So far as possible, an estimate is given of the amounts of each trace element present, and reference is made to all the spectrum lines due to the impurities which have been detected.

In view of the ever-increasing demands for the substances included in these two schemes and for new additions to the list, the need arose for additional manufacturing and analytical facilities. Massrs.
Adam Hilger, Ltd., have therefore entered into an agreement with Messrs. Johnson, Matthey and Co., Ltd., whereby the latter will in future undertake the supply of these substances and the control of their purity at their Research Laboratories, Wembley, Middlesex, where many of them will be made. Dr. Judd Lewis, who acted as consultant for Adam Hilger, Ltd., for many years and was chiefly responsible for the development of the "H. S." and "Specpure" schemes, has been engaged in that capacity by Messrs. Johnson, Matthey and Co., Ltd., and the staff of the Spectrographic Department of their Laboratories has been augmented by the appoint ment of Mr. D. M. Smith, formerly in charge of spectrographic investigations at the British NonFerrous Metals Research Association. Future sales of "H. S." and "Specpure" substances will be made only by Messrs. Johnson, Matthey and Co., Ltd., from their head office at $73-83$ Hatton Garden, London, E.C.1.

\section{Official Topographic Maps}

OFFICIAL large-scale maps are available for comparatively few parts of the world outside western and central Europe, including the British Isles, the eastern United States, India, much of Burma, several of the Netherlands East Indies and Japan. South America, Africa and Australia each have few areas of such detailed survey. In the April number of the Ceographical Review, a coloured world map on a scale of 1 to $50,000,000$ compiled by R. R. Platt shows the distribution of official topographic maps as available at the outbreak of war in 1939. It covers scales up to and including $1: 253,440$ (4 miles to 1 in.). Three categories are recognized, scales of 1 mile to $1 \mathrm{in}$. or larger, those of $1-2$ miles to 1 in. and those of less than 2 miles down to 4 miles. Under each category an attempt has been made to distinguish between maps based on topographic survey on which relief is shown by contours or hachures, and maps of less complete detail with relief shown by form lines or hill shading. As a general rule, only maps produced by States for their own territory are shown, but there are some few exceptions. Compilations produced by an official agency of one country in the territory of another are not shown.

\section{Russian Papers on Pure and Applied Mathematics}

AMONG Russian periodicals and books recently received are several containing papers on pure and applied mathematics. A striking feature is the many investigations of elasticity problems in Applied Mathematics and Mechanics. There are also many other papers of considerable interest, for example, the paper on the flow of a gas at supersonic velocities by V. S. Tatarenchik (App. Maths. and Mechanics, 8, 401; 1943), which should be compared with current investigations by Southwell and his colleagues (Nature, 154, 90 and $834 ; 1944$ ). N. N. Parijsky gives (Astron. J. S. U., 21, $78 ; 1944$ ) the result of calculations which support Russell's criticism of Jeans' theory of the origin of the solar system. In addition to the journals mentioned above, we have also received a valuable atlas of nomograms, containing thirty-seven plates. All the publications received are being deposited in the Science Museum, South Kensington, London, S.W.7, where they will be available for anyone who desires to consult them. By the aid of the summaries in English or French, 
it should be fairly easy for those entirely ignorant of Russian to understand the results and methods of the papers.

\section{Belgian Visitors to Britain}

THE fourth group of distinguished Belgians to visit Great Britain as representatives of the Belgian Fondation Universitaire and guests of the British Council have arrived in London. They are: Prof. M. Florkin, Faculty of Science and Medicine, Liège ; Prof. F. Albert, Faculty of Medicine, University of Liège ; Prof. F. Bremer, Faculty of Medicine, University of Brussels ; Prof. A. Castille, Faculty of Medicine, Louvain ; Prof. J. C. Firket, Faculty of Medicine, Liège ; Prof. H. R. Frederica, Faculty of Medicine, Liège; M. Jean Willems, director of the National Fund for Scientific Research (see p. 780); and Prof. L. M. Gyselynck, Faculty of Law, Brussels. They are meeting leading British authorities in their particular spheres in universities and research institutions in London, Cambridge, Oxford, Liverpool, Edinburgh, Glasgow and Belfast.

\section{University of London}

Prof. D. Hughes Parry, University professor of English law at the London School of Economics and a member of the Senate since 1930, has been elected vice-chancellor for the year 1945-46.

The title of professor emeritus has been conferred on the following: Prof. Major Greenwood, professor of epidemiology and vital statistics since 1926; Prof. William Wilson, Hildred Carlile professor of physics at Bedford College from 1921 until his retirement in 1944 ; Prof. Harold Simpson, professor of mathematics at Bedford College from 1912 until his retirement in 1944.

Prof. C. Daryll Forde, since 1930 Gregynog professor of geography and anthropology at University College, Aberystwyth, has been appointed to the University chair of anthropology tenable at University College as from October 1, 1945 .

The degree of D.Sc. has been conferred on Ur. E. T. Davies (Birkbeck College), Dr. F. W. Jane (Birkbeck College), Mr. S. G. Soal (Queen Mary College), Mr. A. C. Frazer (St. Mary's Hospital Medical School), Mr. L. A. Allen and Mr. C. G. Johnson.

\section{Summer School in Colloid Science}

The Birmingham and Midlands Section of the Royal Institute of Chemistry has arranged, in co-operation with the Departments of Colloid Science and Physical Chemistry of the University of Cambridge, a Summer School in Colloid. Science in the form of two courses, extending from June 23 to June 30 and June 30 to July 7 respectively. The director of tuition for the School is Dr. A. E. Alexander. Both courses are being opened by Prof. E. K. Rideal, professor of colloid science in the University of Cambridge and president of the Society of Chemical Industry, and the opening lectures are by Dr. W. Clayton, on "Foods as Colloid Systems" (course A), and Dr. E. H. Callow, on "Colloids in Theory and Practice" (course B). Some two hundred research chemists are attending the School.

\section{The Night Sky in July}

NEw moon occurs on July 9d. 13h. 35m., U.T., and full moon on July 25d. 02h. $25 \mathrm{~m}$. The following conjunctions with the moon take place: July 5d. 06h., Mars $3^{\circ}$ N. ; July 6d. 02h., Venus $0 \cdot 4^{\circ}$ N. ; July 11d. 10h., Mercury $2^{\circ}$ S.; July 14d. 12h., Jupiter $4^{\circ} \mathrm{S}$. Only one occultation takes place in July, 20 Ceti reappearing on July 30 d. $00 \mathrm{~h}$. $37 \cdot 7 \mathrm{~m}$. ; the time refers to the latitude of Greenwich. Mercury sets at $21 \mathrm{~h} .26 \mathrm{~m}$., and $20 \mathrm{~h}$. $22 \mathrm{~m}$. at the beginning and end of the month respectively, attaining its greatest easterly elongation on July 23, and is not very well placed for observation during the month. Venus is a conspicuous object in the early morning hours, rising at $1 \mathrm{~h} .30 \mathrm{~m}$. and $1 \mathrm{~h} .08 \mathrm{~m}$. at the beginning and end of the month respectively. Mars moves from the constellation of Aries into Taurus during July and rises at $0 \mathrm{~h} .53 \mathrm{~m}$. on July 1 and $23 \mathrm{~h}$. $18 \mathrm{~m}$. on July 31. Jupiter sets at $23 \mathrm{~h} .15 \mathrm{~m}$. at the beginning of the month and at $21 \mathrm{~h} .27 \mathrm{~m}$. on July 31 , about an hour and a half after sunset, and is not easily observed. Saturn sets about quarter of an hour before the sun on July 1 and is not favourably placed for observation. The earth is at aphelion on July 5 .

A total eclipse of the sun takes place on July 9, partly visible as a partial eclipse at Greenwich, where the eclipse begins at $12 \mathrm{~h} .45 \mathrm{~m}$. and ends at $15 \mathrm{~h} .11 \mathrm{~m}$. The magnitude of the eclipse at Greenwich is 0.61 . The central line commences in long. $115^{\circ} 57^{\prime} \mathrm{W}$. and lat. $44^{\circ} 23^{\prime} \mathrm{N}$., and ends in long. $72^{\circ} 33^{\prime} \mathrm{E}$., and lat. $41^{\circ} 43^{\prime} \mathrm{N}$.

\section{Announcements}

Prof. Arnold N. ShImmin, now acting professor of industrial relations in the University of Leeds, has been appointed to the newly instituted chair of social science in the Department of Economics of the University.

Dr. Kathleen Lonsdale has been appointed by the managers of the Royal Institution to be Dewar Research Fellow in succession to Dr. A. R. Ubbelohde.

The Committee of Privy Council for the Organisation and Development of Agricultural Research has appointed Prof. T. G. B. Osborn, Dr. J. L. Simonsen, and Mr. W. J. Wright as members of the Agricultural Research Council in succession to Prof. E. J. Salisbury, Sir Robert Robertson and Sir Robert Greig, whose terms of office as members of the Council have expired.

The Library of the Chemical Society is now re maining open for longer hours; it is open from 10 a.m. to 6 p.m. on Mondays to Fridays and 10 a.m. to 5 p.m. on Saturdays.

The fifth number of the Revre d'Alger published by the University of Algiers includes an interpretation of the American constitution, under the title "The Function of the President of the United States", by A. Heekscher, an article by G. Darmois on "The Tercentenary of the Birth of Newton with an Appreciation of his Work" ; and one by J. Malmejac and S. Cruck on "Penicillin : History of a Recent Discovery in Medical Therapy". G. Cohen contributes a note on the Free School of High Studies at New York, urging the creation in Paris of a similar school for American students living in France, and M. Koch a survey of the French Rhine and its economic and imperial role.

ERRATUM.--In his communication on "Calculation of the Results of Microbiological Assays" in Nature of May 26, Mr. Eric C. Woods states that on p. 633, line 11, "2 $\mu \mathrm{gm}$." should read " $0 \cdot 1 \mu \mathrm{gm} . "$. 